\title{
Vitamin D levels in women of reproductive age group- where do we stand?
}

\author{
Manish Raj Kulshrestha1, Rupita Kulshrestha,"* \\ Assistant Professor, ${ }^{1}$ Dept. of Biochemistry, Dr. Ram Manohar Lohia Institute of Medical Sciences, Lucknow, ${ }^{2}$ Dept. of \\ Obstetrics and Gynecology, Mayo Institute of Medical Sciences, Barabanki, Uttar Pradesh, India
}

*Corresponding author:

Email: rupita.kulshrestha@gmail.com

\begin{abstract}
Vitamin D is a steroid hormone which is fat soluble and activated in kidneys. It plays multiple roles including regulation of cellular growth and differentiation, metabolic modifications, immunity, insulin resistance, cardiovascular disease, malignancies and also various reproduction related states like preeclampsia, preterm birth and gestational diabetes, along with calcium and phosphorous regulation in the body.

In present study, we analyzed serum vitamin D levels in 100 women of reproductive age group (15-45 years). Surprisingly, only $7 \%$ of the women were found to have sufficient vitamin D level while $19 \%$ had insufficient level and $74 \%$ were deficient. Such alarming community wide deficiency raises concern. Especially in this reproductive age group the women are liable to have rickets, osteoporosis, osteomalacia, low fertility and increased risk for adverse pregnancy outcomes. Pre-conception vitamin D supplementation is simple, easy, and inexpensive method which can prevent such grave outcomes.
\end{abstract}

Keywords: Vitamin D, Women, Reproductive age group, Deficiency.

Introduction: Vitamin D is a steroid hormone which is fat soluble and plays multiple roles. Its metabolically active form is cholecalciferol also known as vitamin D3. The main source of vitamin D3 is by its synthesis in the skin under the influence of sunlight.

This vitamin D3 undergoes enzymatic conversion to its active metabolite calcitriol in the liver and kidney by the action of 25- hydroxylase and 1 alpha hydroxylase respectively. ${ }^{1}$

Of the total requirement about $80 \%$ is obtained from sun exposure. ${ }^{2}$ In the tissues vitamin $\mathrm{D}$ exerts its form by binding to vitamin $\mathrm{D}$ receptor present in the nucleus. ${ }^{3}$

Along with the regulation of calcium, bone metabolism, mineral homeostasis ${ }^{4}$ vitamin D has been found to play an important role in regulation of cellular growth and differentiation, metabolic modifications, immunity, insulin resistance, cardiovascular disease, malignancies various disease conditions and also underlying the pathogenesis of various reproduction related states like preeclampsia, preterm birth and gestational diabetes. ${ }^{4-6}$

\section{Materials and Methods}

The study was conducted at Dr Ram Manohar Lohia Institute of Medical Sciences, Lucknow. 100 blood samples were collected consecutively from women of reproductive age group (15-45 years) coming to sample collection center and provided consent for the study. The subjects with renal disease or cancer or on vitamin D supplementation were excluded. The blood samples were centrifuged for ten minutes at $3000 \mathrm{rpm}$. The vitamin D levels were analyzed at Advia Centaur XP using commercially available kits from Siemens Healthcare.

The deficiency was taken as vitamin $\mathrm{D}$ level below $10 \mathrm{ng} / \mathrm{ml}$, insufficiency $10-29 \mathrm{ng} / \mathrm{ml}$ and above 30 $\mathrm{ng} / \mathrm{ml}$ as sufficient as per kit insert from the manufacturer.

\section{Results}

Only $7 \%$ of the women were found to have sufficient vitamin D level while 19\% had insufficient level and $74 \%$ were deficient. Even more noticeable finding was that $50 \%$ of the women had vitamin D level below $4.2 \mathrm{ng} / \mathrm{ml}$ (below the limit of detection of the kit).

The mean levels of vitamin $\mathrm{D}$ in each group were $<4.20 \mathrm{ng} / \mathrm{ml}, 18.13 \pm 5.58$ and $39.07 \pm 9.62$ in deficiency, insufficiency and sufficiency groups. (Table 2)

Table 1: Demographic details of the study group

\begin{tabular}{|l|c|c|}
\hline Demographics & Categories & n \\
\hline Age group & $16-25$ & 20 \\
\hline & $26-35$ & 35 \\
\hline & $36-45$ & 45 \\
\hline Rural/Urban & Rural & 63 \\
\hline & Urban & 37 \\
\hline Parity & 0 & 08 \\
\hline & $1-2$ & 19 \\
\hline & $3-4$ & 44 \\
\hline Diet & $>4$ & 29 \\
\hline & Vegetarian & 39 \\
\hline Religion & Non- Vegetarian & 61 \\
\hline & Hindu & 52 \\
\hline & Muslims & 41 \\
\hline Education & Others & 07 \\
\hline & Literate & 86 \\
\hline & Illiterate & 14 \\
\hline
\end{tabular}


Table 2: The vitamin D levels in all the three groups

\begin{tabular}{|l|c|c|}
\hline Group & $\mathbf{N}$ & Mean $(\mathbf{n g} / \mathbf{m l})$ \\
\hline 1.00 & 74 & $<4.20$ \\
\hline 2.00 & 19 & $18.13 \pm 5.58$ \\
\hline 3.00 & 7 & $39.07 \pm 9.62$ \\
\hline
\end{tabular}

The vitamin D levels were significantly correlated with age of the women $(r=0.245 ; \mathrm{p}=0.014)$.

\section{Discussion}

Vitamin D is endogenously produced in the skin following exposure to sufficient sunlight particularly ultraviolet B radiation with a wavelength of 280-315 $\mathrm{nm} .^{7}$ While the symptoms of vitamin D deficiency are not evident until severe deficiency occurs however laboratory tests requires peripheral venous blood sample and the level assessment can be done without much expertise. The risk population includes infants, children and women in the reproductive as well as postmenopausal age group. ${ }^{4}$

As also seen by other authors the prevalence of vitamin D deficiency is rising in women of child bearing age. ${ }^{8-13}$ While studies from various parts of the country also reported similar results. ${ }^{7,14-17}$

Study by few authors has highlighted the deficiency of the vitamin in specific season of the year like spring, however it was not so in the present study. ${ }^{18}$ Due to lesser exposure to sun during the winter season, deficiency of vitamin D was observed in summer season in a study in Canada. ${ }^{13}$

The status of vitamin D level was not deficient in women with higher education and attributed it to access to better health due to better economic level and thus intake of vitamin D supplements and fortified food. ${ }^{19-21}$

Obesity which is commonly observed in women of child bearing age group has been attributed by some in causing deficiency and hypothesized accumulation of vitamin $\mathrm{D}$ in adipose tissue leading to lower bioavailability. ${ }^{22}$

Prevalence of deficiency was more in women covered with a scarf or hijab ${ }^{23}$ and was not so in present study. Outdoor activities lead to exposure to sun and thus synthesis of vitamin D. However, India being a low socio-economic country located in the tropical zone, the sunrays are present during the year and even an hour exposure can be adequate. In spite of all this there was observed deficiency.

The food sources of vitamin D are certain seafood like fish which is not consumed by majority of the women in the country follow vegetarian diet and thus deprivation from food source. ${ }^{24}$ Thus, another way of preventing is by fortification of the food. ${ }^{18}$

The diseases due to deficiency may be seen immediately or in the long term. Likewise manifestations limited to the mother only or also to the offspring conceived during the period of deficiency. ${ }^{25-27}$

Especially in this reproductive age group the women are liable to have rickets, osteoporosis, osteomalacia, low fertility and increased risk for adverse pregnancy outcomes. ${ }^{4}$

Study by few authors has implicated vitamin D deficiency as a risk factor for developing carcinoma of colon and breast. ${ }^{28}$ It is also found to have circumstantial evidence of being associated with depression and menstrual symptoms. ${ }^{29,30}$

The treatment for deficiency is not expensive as oral supplements are well tolerated with good absorption of the drug and also has good patient compliance. $^{4}$

Detailed history and examination regarding presence of vitamin D deficiency diseases like rickets, infertility etc, levels of parathyroid hormone, calcium and phosphorus levels were not taken during the data collection and thus forms the limitation of the study.

The increasing prevalence undetected vitamin D deficiency in apparently healthy persons is an area of concern and active research. Vitamin D deficiency even in rural areas and equatorial regions is well documented; however the underlying mechanisms are not clear. Data on the extent of vitamin D deficiency at the population level from most Asian countries, including India, are limited. Kumar et al. in a review of most available data on vitamin D deficiency in India have noted that poor vitamin D status is almost universally reported across all age groups with as many as $95.7 \%$ neonates, $75 \%$ adults and $67 \%$ pregnant women having serum $25 \mathrm{OH}$ vitamin $\mathrm{D}$ levels $<15$ $\mathrm{ng} / \mathrm{mL}$ (deficient). High prevalence of poor vitamin D status as reported above may be attributed to a combination of factors related to geographical location, urbanization, skin pigmentation, changing lifestyle, diet, religious beliefs, air pollution, use of sunscreen and other ways of sun protection or possibly a genetic predisposition to vitamin $\mathrm{D}$ deficiency reported amongst Asian people. ${ }^{4,8}$ Air pollution due to industrial and vehicular emissions forms a cover and absorbs UV radiation preventing it to reach the earth's surface. Pollution has been shown to effect vitamin D status in India and coupled with darker skin pigmentation of Indian skin add to the risk of vitamin D deficiency. Covering of the face and body parts either due to religious or cultural reasons, or as a protection from the extreme heat of the sun could be one of the main reasons attributable to the low vitamin $\mathrm{D}$ status of Indians. Urbanization has resulted in large-scale migration to cities and living in settlements with small cramped homes with very little sunlight. It has also resulted in change in lifestyle of the middle class and the affluent who stay indoors in air-conditioned homes and offices with no direct exposure to sunlight, leading to poor vitamin $\mathrm{D}$ status. ${ }^{31}$

To conclude vitamin D has marked implications on the overall health of the women in the reproductive age group and also the fetus in case of pregnancy. Preconception vitamin D supplementation which is simple, 
easy, and not expensive can prevent the grave outcomes.

\section{References}

1. Alpert PT, Shaikh U. The effects of vitamin D deficiency and insufficiency on the endocrine and paracrine systems. Biol Res Nurs 2007;9(2):117-29.

2. Dawson-Hughes B, Heaney RP, Holick MF, Lips P, Meunier PJ, Vieth R. Estimates of optimal Vitamin D status. Osteoporos Int. 2005;16:713-6.

3. Jones G, Strugnell SA, De Luca HF. Current understanding of the molecular actions of vitamin D. Physiol Rev. 1998;78(4):1193-231.

4. Magdalena Grundmann and Frauke von Versen-Höynck. Vitamin D - roles in women's reproductive health? Reprod Biol Endocrinol. 2011; 9: 146. doi: 10.1186/1477-7827-9-146.

5. Heaney RP. Vitamin D in health and disease. Clin J Am Soc Nephrol. 2008;3(5):1535-41.

6. Perez-Lopez FR, Chedraui P, Fernandez-Alonso AM. Vitamin D and aging: beyond calcium and bone metabolism. Maturitas. 2011;69(1):27-36.

7. Nighat Yaseen Sofi, Monika Jain, Umesh Kapil, Vuthaluru Seenu, Lakshmy Ramakrishnan, Chander Prakash Yadav et al. Levels in Women of Reproductive Age in National Capital Territory of India. Indian J Endocrinol Metab. 2017 Sep-Oct;21(5):731-3.

8. Bodnar LM, Simhan HN, Powers RW, Frank MP, Cooperstein E, Roberts JM. High prevalence of vitamin D insufficiency in black and white pregnant women residing in the northern United States and their neonates. J Nutr. 2007;137(2):447-52.

9. Holmes VA, Barnes MS, Alexander HD, McFaul P, Wallace JM. Vitamin D deficiency and insufficiency in pregnant women: a longitudinal study. Br J Nutr. 2009;102(6):876-81.

10. Johnson LK, Hofs $\varnothing$ D, Aasheim ET, Tanbo T, Holven $\mathrm{KB}$, Andersen LF, Røislien J, Hjelmesæth J. Impact of gender on vitamin $\mathrm{D}$ deficiency in morbidly obese patients: a cross-sectional study. Eur J Clin Nutr. 2012 Jan;66(1):83-90.

11. Datta S, Alfaham M, Davies DP, Dunstan F, Woodhead S, Evans J, Richards B. Vitamin D deficiency in pregnant women from a non-European ethnic minority population-an interventional study. BJOG. 2002;109(8):905-8.

12. Lopes, Vinicius Medina et al. Highly prevalence of vitamin D deficiency among Brazilian women of reproductive age. Arch. Endocrinol. Metab. [online]. 2017, vol.61, n.1, pp.21-7.

13. Claudia Gagnon, Zhong X. Lu, Dianna J. Magliano, David W. Dunstan, Jonathan E. Shaw, Paul Z. Zimmet, Ken Sikaris, Peter R. Ebeling, Robin M. Daly; Low Serum 25-Hydroxyvitamin D Is Associated with Increased Risk of the Development of the Metabolic Syndrome at Five Years: Results from a National, Population-Based Prospective Study (The Australian Diabetes, Obesity and Lifestyle Study: AusDiab), The Journal of Clinical Endocrinology \& Metabolism, Volume 97, Issue 6, 1 June 2012, Pages 1953-61.

14. Sachan A, Gupta R, Das V, Agarwal A, Awasthi PK, Bhatia V. High prevalence of Vitamin D deficiency among pregnant women and their newborns in Northern India. Am J Clin Nutr. 2005;81:1060-4.

15. Paul R, Ray J, Saha R, Daulagajao B, Banerjee AK. Blood Vitamin D levels in a sample population from Eastern India: A pilot study. Int J Biomed Res. 2014;5:8.
16. Daga RA, Laway BA, Shah ZA, Mir SA, Kotwal SK, Zargar AH. High prevalence of Vitamin D deficiency among newly diagnosed youth-onset diabetes mellitus in North India. Arq Bras Endocrinol Metabol. 2012;56:4238.

17. Harinarayan CV, Sachan A, Reddy PA, Satish KM, Prasad UV, Srivani P. Vitamin D status and bone mineral density in women of reproductive and postmenopausal age groups: A cross-sectional study from South India. J Assoc Physicians India. 2011;59:698-704.

18. Davaasambuu Ganmaa, Michael F Holick, Janet W RichEdwards, A. Lindsay Frazier, Dambadarjaa Davaalkham, Boldbaatar Ninjin et al. Vitamin D Deficiency in Reproductive Age Mongolian Women: A Cross Sectional Study. J Steroid Biochem Mol Biol. 2014 Jan;139:1-6.

19. Atiq M, Suria A, Nizami SQ, Ahmed I. Vitamin D status of breastfed Pakistani infants. Acta Paediatr. 1998;87:737-40.

20. Lagunova Z, Porojnicu AC, Lindberg F, Hexeberg S, Moan J. The dependency of vitamin Dstatus on body mass index, gender, age and season. Anticancer Res. 2009;29(9):3713-20.

21. Bischof MG, Heinze G, Vierhapper H. Vitamin D status and its relation to age and body mass index. Hormone Research. 2006;66:211-215.

22. Wortsman J, Matsuoka LY, Chen TC, Lu Z, Holick MF Decreased bioavailability of vitamin D in obesity. Am J Clin Nutr. 2000;72(3):690-3.

23. Nichols EK, Khatib IMD, Aburto NJ, Sullivan KM, Wirth JP,Serula MK. Vitamin D staus and determinants of deficiency among non pregnant Jordanian women of reproductive age. European Journal of Clinical Nutrition (2012) 66,751-6.

24. Calvo MS, Whiting SJ, Barton CN. Vitamin D fortification in the United States and Canada: Current status and data needs. Am J Clin Nutr. 2004;80(6 Suppl):1710S-6S.

25. Stene LC, Ulriksen J, Magnus P, Joner G. Use of cod liver oil during pregnancy associated with lower risk of type I diabetes in the offspring. Diabetologia. 2000;43:1093-8.

26. Zhang C, Qiu C, Hu FB, David RM, van Dam RM, Bralley A, Williams MA. Maternal plasma 25hydroxyvitamin D concentrations and the risk for gestational diabetes mellitus. PLoS ONE. 2008;3(11):e3753.

27. Viljakainen HT, Saarnio E, Hytinantti T, Miettinen M, Surcel H, Mäkitie O, Andersson S, Laitinen K, LambergAllardt C. Maternal vitamin D status determines bone variables in the newborn. J Clin Endocrinol Metab. 2010;95(4):1749-57.

28. Garland CF, Garland FC, Gorham ED, et al. The role of vitamin D in cancer prevention. American Journal of Public Health. 2006;96:252-61.

29. Thys-Jacobs S. Micronutrients and the premenstrual syndrome: the case for calcium. J Am Coll Nutr. 2000;19:220-227.

30. ERB Johnsonn. Vitamin D and the Occurrence of Depression: Causal Association or Circumstantial Evidence?. Nutr Rev. 2009 Aug;67(8):481-92.

31. Trilok Kumar G, Chugh R, Eggersdorfer M. Poor Vitamin D Status in Healthy Populations in India: A Review of Current Evidence. Int J Vitam Nutr Res. 2015;85(3-4):185-201. 